\title{
Does susceptibility to heat stress confound screening for drought tolerance in rice?
}

\author{
Krishna S. V. Jagadish ${ }^{\mathrm{A}}$, Jill E. Cairns ${ }^{\mathrm{D}}$, Arvind Kumar ${ }^{\mathrm{A}}$, Impa M. Somayanda ${ }^{\mathrm{B}}$ \\ and Peter Q. Craufurd ${ }^{\mathrm{C}, \mathrm{E}, \mathrm{F}}$ \\ APlant Breeding, Genetics, and Biotechnology Division, International Rice Research Institute (IRRI), \\ DAPO Box 7777, Metro Manila, Philippines. \\ ${ }^{B}$ Crop and Environmental Sciences Division, International Rice Research Institute (IRRI), DAPO Box 7777 , \\ Metro Manila, Philippines. \\ CPlant Environment Laboratory, University of Reading, Cutbush Lane, Shinfield, Reading RG2 9AF, UK. \\ DPresent address: Km. 45, Carretera Mexico-Veracruz El, Batan, Texcoco, Edo. de México, CP 56130 México.

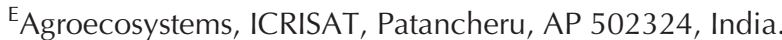 \\ FCorresponding author. Email: p.craufurd@cgiar.org
}

\begin{abstract}
Drought affected rice areas are predicted to double by the end of this century, demanding greater tolerance in widely adapted mega-varieties. Progress on incorporating better drought tolerance has been slow due to lack of appropriate phenotyping protocols. Furthermore, existing protocols do not consider the effect of drought and heat interactions, especially during the critical flowering stage, which could lead to false conclusion about drought tolerance. Screening germplasm and mapping-populations to identify quantitative trait loci (QTL)/candidate genes for drought tolerance is usually conducted in hot dry seasons where water supply can be controlled. Hence, results from dry season drought screening in the field could be confounded by heat stress, either directly on heat sensitive processes such as pollination or indirectly by raising tissue temperature through reducing transpirational cooling under water deficit conditions. Drought-tolerant entries or droughtresponsive candidate genes/QTL identified from germplasm highly susceptible to heat stress during anthesis/flowering have to be interpreted with caution. During drought screening, germplasm tolerant to water stress but highly susceptible to heat stress has to be excluded during dry and hot season screening. Responses to drought and heat stress in rice are compared and results from field and controlled environment experiments studying drought and heat tolerance and their interaction are discussed.
\end{abstract}

Additional keywords: flowering, heat, spikelet fertility, tissue temperature.

\section{Introduction}

Drought - defined as a condition where available soil water or moisture is insufficient to support average crop production affects 23 million ha of rice regularly (Pandey et al. 2007). Anticipated changes in climate in future are likely to double the area affected by drought, especially in the tropical and subtropical regions of the world (IPCC 2007). Developing improved drought-tolerant rice (Oryza sativa L.) germplasm for drought prone areas is a major focus of many agricultural research programs (Virk et al. 2003; Atlin et al. 2006; Ouk et al. 2006; Pinheiro et al. 2006; Bernier et al. 2007; Steele et al. 2007; Venuprasad et al. 2007, 2008; Kumar et al. 2008; Verulkar et al. 2010). Drought most often occurs during dry, hot periods with limited or no precipitation. Moreover, drought seldom occurs in isolation; often interacting with other abiotic and biotic stresses (Ceccarelli et al. 2004): most commonly with heat stress (Rizhsky et al. 2002, 2004; Mittler 2006). Heat stress is associated with temperatures rising above an optimum, which may adversely affect the physiological activities (for e.g. photosynthesis; Vani et al. 2001) and lead to an altered path of development (e.g. reduced grain quality; Kobata and Uemuki 2004). Further, general circulation models also predict an increase in mean global temperatures by $2.0-4.5^{\circ} \mathrm{C}$ with increased variability over the mean by the end of the century (IPCC 2007), greatly exacerbating drought and heat stress interactions.

Using spatial techniques and cropping pattern data from the rice almanac (Maclean et al. 2003; Siddiq 2006), Wassmann et al. (2009) examined the occurrence of drought and heat stress experienced by the rice crop in Asia. They reported that high-temperature stress during the susceptible/critical flowering to early grain filling period would coincide with drought stress in Bangladesh, eastern India, southern Myanmar, and northern Thailand (Fig. 1). For example, in Bangladesh, rice is grown in large areas during the 'boro' season (dry season, DecemberApril) with temperatures ranging from $36-40^{\circ} \mathrm{C}$ during the critical flowering stage. Hence, with the frequency of high temperatures during crop growing seasons predicted to increase in many areas, drought exacerbated by heat stress 

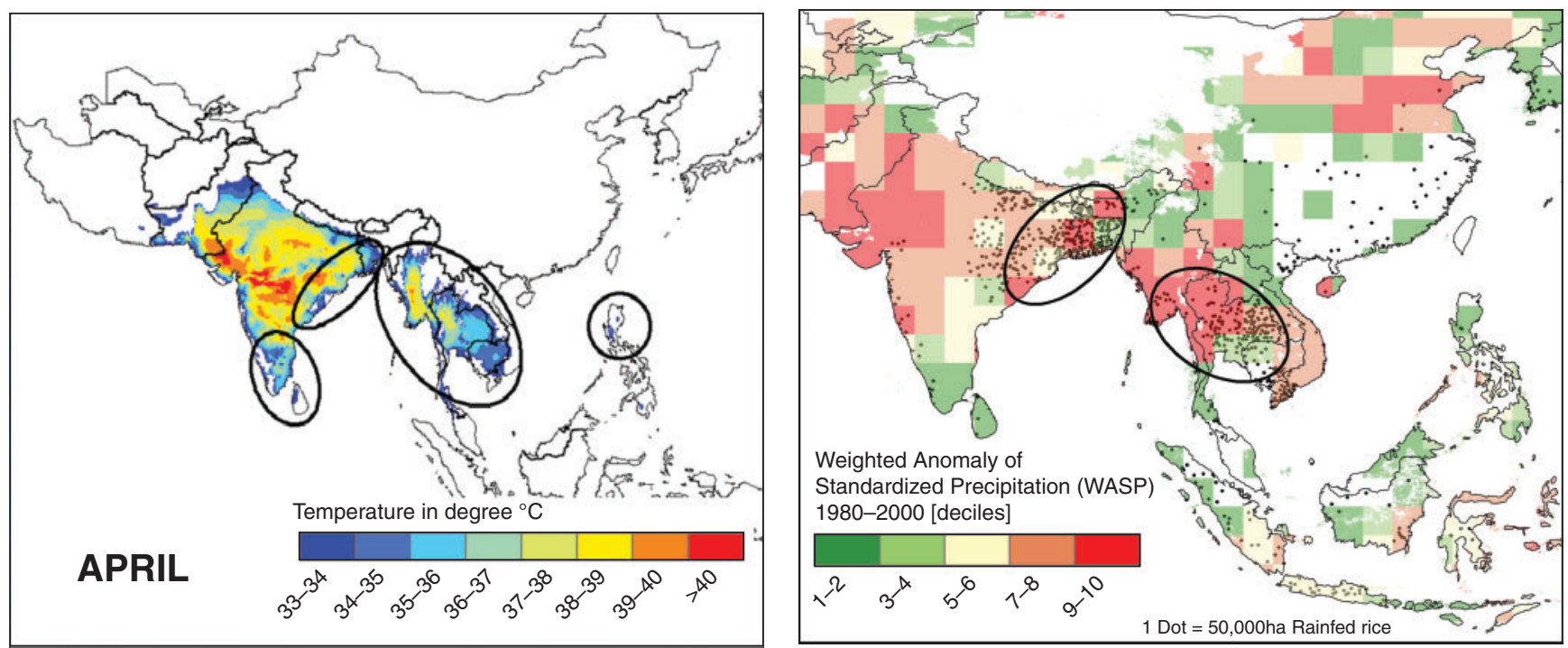

Fig. 1. Geographic illustration of Asia's rice-producing regions highlighting maximum temperatures $>33^{\circ} \mathrm{C}$ (monthly averages) and (a) ellipsis depict hightemperature regions where rice crop is at flowering and/or ripening stage in April. For a similar analysis during the other months of the year see Wassmann et al. (2009). (b) The weighted anomaly standardised precipitation (WASP) index, which is based on average monthly precipitation data from 1980 to 2000 at a resolution of $2.5^{\circ}$. Both these maps show regions which could be potentially vulnerable to combined high temperatures and drought stress under current climates and more so during future warmer and drier climates. Reprinted from Advances in Agronomy 102, Wassmann R, Jagadish SVK, Sumfleth K, Pathak H, Howell G, Ismail A, Serraj R, Redoña E, Singh RK, Heuer S. Regional Vulnerability of Climate Change Impacts on Asian Rice Production and Scope for Adaptation. 91-133, Copyright (2011), with permission from Elsevier.

(Battisti and Naylor 2009) will have serious implications for future rice production in drought prone areas.

\section{Effect of temperature and drought on fertility}

The effects of high temperature and drought at various stages of floral development leading to spikelet sterility are compared in Table 1, and as described below, these effects are broadly similar at all stages except flowering responses and early grainfilling. High temperatures during the reproductive stage (booting/meiosis, anthesis; pollination and post-fertilisation) in rice has a strong negative effect on yield, with the maximum yield depression occurring when high temperatures occur during anthesis, pollination and pollen germination (i.e. flowering) (Yoshida et al. 1981; Prasad et al. 2006; Jagadish et al. 2007, 2008, 2010a, 2010b). High temperatures before flowering, during booting which coincides with microsporogenesis, also affects fertility but to a lesser extent compared with flowering. There is genetic variation in the critical temperature thresholds at which spikelet fertility falls below 50\% (Yoshida et al. 1981). The tolerant cv. N22 has a critical temperature of $36.5^{\circ} \mathrm{C}$ compared with $32^{\circ} \mathrm{C}$ in a susceptible entry IR747B-2-6. In rice, high temperatures (up to $41^{\circ} \mathrm{C}$ ) 1 hour after pollination has no effect on spikelet fertility. Critical temperatures have also been measured for other reproductive stages/processes and in peanut (Arachis hypogea L.) for example, the critical temperature varies from $33^{\circ} \mathrm{C}$ during meiosis, pollination and fertilisation (Vara Prasad et al. 2001) to $36^{\circ} \mathrm{C}$ for fruit-set (Vara Prasad et al. 2000). Likewise, in 21 peanut genotypes average temperature thresholds for pollen germination and pollen tube growth were 30.1 and $34.4^{\circ} \mathrm{C}$, respectively (Kakani et al. 2002).
In rice, spikelet sterility at high temperatures is closely associated with abnormal anther dehiscence (Matsui et al. 2000; Jagadish et al. 2010a), resulting in less pollen and germinated pollen on the stigma (Yoshida et al. 1981). Pollen tube growth may also be reduced causing sterility (Jagadish et al. $2010 a$ ). Heat tolerant genotypes are able to deposit sufficient (10-20) viable pollen grains on the stigma to ensure successful fertilisation.

The largest reduction in yield occurs when drought stress coincides with the flowering stage (Cruz and O'Toole 1984; Boonjung and Fukai 1996). Water stress at panicle initiation ( $\sim 35$ days before flowering) and more so at heading reduces peduncle elongation, thereby inhibiting complete exsertion of the panicle out of the flag leaf sheath, which, in turn, reduces fertility because spikelets that remain within the leaf sheath have lower fertility (Cruz and O'Toole 1984). Further, rice plants exposed to drought or heat stress 3 days before heading had peduncle lengths reduced by 24 and $8 \%$, respectively, which resulted in a significantly higher number of spikelets trapped in the leaf sheath but only with drought stress (Rang et al. 2011). Drought stress at panicle initiation also reduces the number of spikelet primordia (Boonjung and Fukai 1996; Mackill et al. 1996).

\section{Effect of drought and $\left[\mathrm{CO}_{2}\right]$ on tissue/canopy temperature}

An immediate response to drought stress is the reduction of transpiration (through partial stomatal closure), which, in turn, increases canopy and tissue temperatures (Rizhsky et al. 2002, 2004) due to less transpiration cooling. Using infrared thermometry during 1981 and 1982 dry-season drought 
Table 1. Physiological impacts of high temperature and drought stress on different developmental stages in rice

\begin{tabular}{|c|c|c|c|}
\hline Developmental stage & High temperature stress & Drought stress & References \\
\hline Seedling & $\begin{array}{l}\text { Thylakoid structure disorganised, } \\
\text { significant loss in PSII activity }\end{array}$ & $\begin{array}{l}\text { Reduced leaf expansion growth } \\
\text { and photosynthesis }\end{array}$ & $\begin{array}{l}\text { Vani et al. }(2001)^{\mathrm{A}} \text {; Singh et al. } \\
\quad(1996)^{\mathrm{B}} ; \text { Boonlertnirun et al. } \\
(2007)^{\mathrm{B}}\end{array}$ \\
\hline Panicle initiation & - & Reduced spikelet number & Allah et al. $(2010)^{\mathrm{B}}$ \\
\hline Booting/microsporogenesis & $\begin{array}{l}\text { Drastic reduction in pollen } \\
\text { production and impaired cell } \\
\text { division of microspore mother } \\
\text { cells }\end{array}$ & $\begin{array}{l}\text { Reduced number of viable pollen; } \\
\text { pollen abortion; dead } \\
\text { microspores }\end{array}$ & $\begin{array}{l}\text { Prasad et al. }(2006)^{\mathrm{A}} \text {; Takeoka } \\
\text { et al. }(1992)^{\mathrm{A}} \text {; Sheoran and } \\
\text { Saini }(1996)^{\mathrm{B}} \text { Nguyen et al. } \\
(2009)^{\mathrm{B}}\end{array}$ \\
\hline Pollen development & $\begin{array}{l}\text { Decreased pollen volume and } \\
\text { diameter; reduced starch } \\
\text { accumulation; stamen } \\
\text { hypoplasia }\end{array}$ & $\begin{array}{l}\text { Inhibition of starch accumulation; } \\
\text { stamen hypoplasia and } \\
\text { abnormal organogenesis }\end{array}$ & $\begin{array}{l}\text { Takeoka et al. }(1991)^{\mathrm{A}} \text {; Matsui } \\
\text { et al. }(2000)^{\mathrm{A}} \text {; Sheoran and } \\
\text { Saini }(1996)^{\mathrm{B}} \text {; Liu and Bennett } \\
(2010)^{\mathrm{B}}\end{array}$ \\
\hline Pistil development & Pistil hyperplasia & - & Takeoka et al. $(1991)^{\mathrm{A}}$ \\
\hline Flowering & $\begin{array}{l}\text { Reduction in days to flowering; } \\
\text { earlier time peak flowering; } \\
\text { shorter flowering period }\end{array}$ & $\begin{array}{l}\text { Days to flowering extended; } \\
\text { flowering rate reduced; } \\
\text { extended flowering duration }\end{array}$ & $\begin{array}{l}\text { Ishimaru et al. }(2010)^{\mathrm{A}} ; \text { Jagadish } \\
\text { et al. }(2008)^{\mathrm{A}} \text {; Prasad et al. } \\
(2006)^{\mathrm{A}} ; \text { Pantuwan et al. } \\
(2002 b)^{\mathrm{B}} \text { Jongdee } \text { et al. } \\
(2006)^{\mathrm{B}} \text {; Rang } \text { et al. }(2011)^{\mathrm{A}, \mathrm{B}}\end{array}$ \\
\hline $\begin{array}{l}\text { Anther dehiscence and } \\
\text { pollination }\end{array}$ & $\begin{array}{l}\text { Abnormal anther dehiscence; low } \\
\text { or no pollen count on stigma; } \\
\text { asynchronous pollination }\end{array}$ & $\begin{array}{l}\text { Incomplete panicle exsertion and } \\
\text { peduncle elongation; reduced } \\
\text { anther dehiscence; spikelet } \\
\text { abortion }\end{array}$ & $\begin{array}{l}\text { Matsui and Omasa }(2002)^{\mathrm{A}} \text {; } \\
\text { Matsui et al. }(1997) b^{\mathrm{A}} \text {; Yoshida } \\
\text { et al. }(1981)^{\mathrm{A}} \text {; Jagadish } \text { et al. } \\
(2010)^{\mathrm{A}} \text {; Rang et al. }(2011)^{\mathrm{A}, \mathrm{B}} \text {; } \\
\text { Liu et al. }(2006)^{\mathrm{B}}\end{array}$ \\
\hline $\begin{array}{l}\text { Pollen germination and } \\
\text { fertilisation }\end{array}$ & $\begin{array}{l}\text { Reduced pollen viability and rate } \\
\text { of pollen tube growth, spikelet } \\
\text { sterility }\end{array}$ & $\begin{array}{l}\text { Viability and pollen tube growth } \\
\text { rate reduced; spikelet sterility }\end{array}$ & $\begin{array}{l}\text { Yoshida et al. }(1981)^{\mathrm{A}} ; \text { Prasad } \\
\text { et al. }(2006)^{\mathrm{A}} ; \text { Jagadish et al. } \\
(2010 b)^{\mathrm{A}} ; \text { Liu et al. }(2006)^{\mathrm{B}} ; \\
\text { Rang et al. }(2011)^{\mathrm{A}, \mathrm{B}}\end{array}$ \\
\hline Early grain filling & $\begin{array}{l}\text { Chalkiness; shorter grain filling } \\
\text { period; reduced grain weight }\end{array}$ & Grain abortion and chaffiness & $\begin{array}{l}\text { Fitzgerald et al. }(2009 a) \text {, } \\
\qquad(2009 b)^{\mathrm{A}} ; \text { Kobata and Uemuki } \\
(2004)^{\mathrm{A}} \text {; O'Toole and Namuco } \\
(1983)^{\mathrm{B}}\end{array}$ \\
\hline
\end{tabular}

${ }^{\mathrm{A}}$ High temperature studies.

${ }^{\mathrm{B}}$ Drought stress studies.

screenings at IRRI Garrity and O'Toole (1995) recorded a canopy temperature increase from 28 to $37^{\circ} \mathrm{C}$ during drought stress (after accounting for cloud cover, wind speed, and minimising solar angle interactions). Furthermore, there was a significant negative relationship $\left(r^{2}=-0.63, P<0.05\right)$ between yield and midday canopy temperature on the day of $50 \%$ flowering with complete sterility when midday temperatures were $\geq 34^{\circ} \mathrm{C}$ (Fig. 2). They concluded that entries with lower canopy temperature or higher canopy: air difference were better drought avoiders, similarly capable of avoiding combined drought and heat stress. Fischer et al. (1989) in maize (Zea mays L.) recorded a significantly negative relationship $(r=-0.73, P<0.01)$ between canopy temperature and yield under severe water stress. Similar increase in relative leaf temperature of $4.4-5.4{ }^{\circ} \mathrm{C}$ has also been observed in cotton (Gossypium barbadense L. cv. PF-15) 6 days after drought stress was imposed (Cohen et al. 2005). The soil moisture content ranging from 25 to $175 \%$, resulted in corresponding variation in canopy temperature of rice, with lower soil moisture recording a higher canopy temperature (Zhang et al. 2007). Evapotranspiration and energy-exchange studies in flooded and aerobic rice have shown that under aerobic conditions, a large proportion of the available net radiation

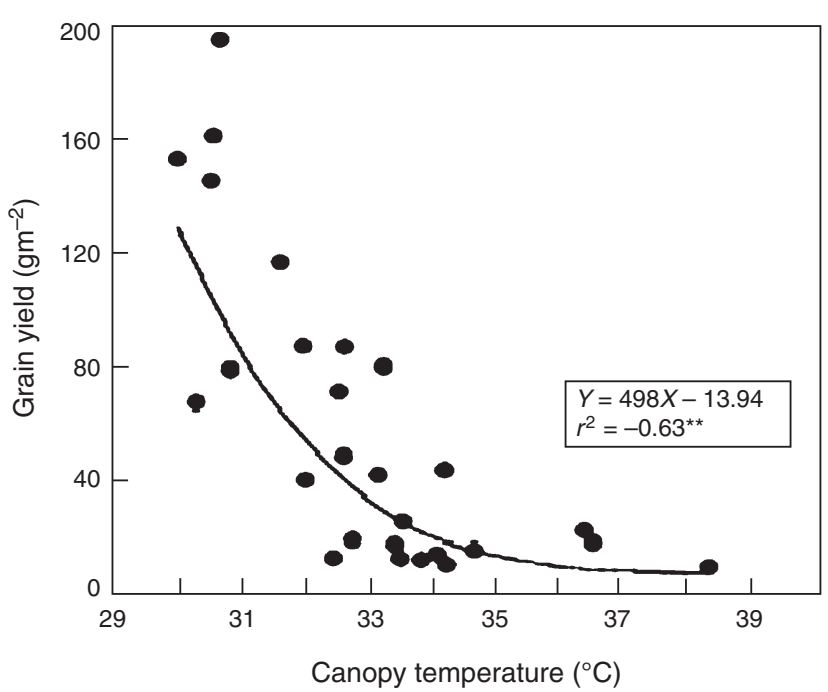

Fig. 2. Relationship between rice grain yield and canopy temperature in 27 cultivars on the date of $50 \%$ flowering during 1982 dry-season drought screening at IRRI. (Garrity and O'Toole 1995; reprinted with permission from The American Society of Agronomy). 
was used for sensible heat transfer that warmed the surrounding ambient air temperature (Alberto et al. 2009). With the predicted doubling $\left(\sim 700 \mu \mathrm{mol} \mathrm{mol}^{-1}\right)$ of $\left[\mathrm{CO}_{2}\right]$ by the end of the century (IPCC 2007), grain yields may increase at lower temperatures due to the $\mathrm{CO}_{2}$ fertilisation effect (Long and Ort, 2010) but at higher temperatures yields will be severely affected by $\left[\mathrm{CO}_{2}\right] \times$ temperature interactions, such as in rice (Matsui et al. 1997a) and sorghum (Sorghum bicolor (L.) Moench, Vara Prasad et al. 2006). This has been attributed to higher canopy temperature at elevated $\left[\mathrm{CO}_{2}\right]$ due to stomatal closure and reduced transpirational cooling. For example, Vara Prasad et al. (2006) recorded a canopy temperature increase of $1.3-2.7^{\circ} \mathrm{C}$ at $700 \mu \mathrm{mmol}^{-1} \mathrm{CO}_{2}$ in temperature regimes of $32 / 22^{\circ} \mathrm{C}$ to $44 / 34{ }^{\circ} \mathrm{C}$ in sorghum. Furthermore, Matsui et al. $\left(1997 a\right.$ ) recorded a $1^{\circ} \mathrm{C}$ reduction in the critical air temperature induced spikelet sterility with elevated $\left[\mathrm{CO}_{2}\right]$. Hence, in future climates with increasing frequency and intensity of droughts combined with increased $\left[\mathrm{CO}_{2}\right]$, the adverse influence of warmer temperatures leading to higher canopy temperatures that exceed critical levels are likely to adversely affect yield formation processes in rice and other crop species.

\section{Combined drought and heat stress}

Relatively little is known about the interaction between drought and heat stress in rice (Moffat 2002; Shah and Paulsen 2003). In tobacco (Nicotiana tabacum L. cv. Xanthi-nc NN), heat stress caused stomata to open, whereas, under drought stress or combined drought and heat stress, stomata remained closed, resulting in a $2-3^{\circ} \mathrm{C}$ increase in leaf temperature relative to leaves subjected to heat stress only (Rizhsky et al. 2002).

The effects of drought and heat stress could be additive (Barnabás et al. 2008), with the combined effect of both stresses shown to be greater than that of each stress individually in sorghum (Craufurd and Peacock 1993) and barley (Hordeum vulgare L., Savin and Nicolas 1996). Recently, Rang et al. (2011) studied the effect of heat and drought independently and in combination at flowering in five rice genotypes with known levels of tolerance/susceptibility to either heat or drought. The heat tolerant cultivar N22 had high spikelet fertility under heat, drought and the combined stress. Conversely, the heat-sensitive and drought-tolerant cultivars Apo and Moroberekan were on par with N22 under drought stress but recorded the lowest spikelet fertility under combined stresses, suggesting a negative interaction between heat and drought, wherein susceptibility to heat stress dominated the interaction.

One drought tolerance strategy is to maintain turgor in both the male and female reproductive organs to ensure normal reproductive processes during anthesis (Saini and Aspinall 1982). In rice, the lemma and palea, to a certain extent, protect the heat-sensitive reproductive organs (anthers, stigmas) from direct radiative heating effects before anthesis. However, at anthesis, the spikelet is open for $\sim 45$ min (Ekanayake et al. 1989), with both anthers and stigma exposed directly to high ambient air temperatures and high transpirational demand. When severe drought coincides with anthesis, canopy temperature is known to increase beyond critical levels (Garrity and O'Toole 1995). This results in increased transpiration from the spikelets and a loss of moisture needed for pollen swelling, in turn, reducing anther dehiscence (Matsui et al. 2000), and, thus, affecting the succeeding processes involved in grain formation. It is, therefore, essential to test putatively drought tolerant lines for their heat tolerance, and not to ascribe tolerance or susceptibility to drought only.

\section{Screening for drought tolerance}

One major limitation to the improvement of rice for droughtprone areas has been the lack of appropriate screening methods to routinely and reliably impose drought in order to select tolerant lines: both true tolerance and those exhibiting plasticity. Breeders have tried several methods including latesown wet-season reproductive-stage screening (Jongdee et al. 2002; Pantuwan et al. 2002a; Kumar et al. 2008), line-source sprinkler screening (Garrity and O'Toole 1994), rain-out shelter screening (Lilley and Fukai 1994), and dry-season reproductivestage screening (Atlin and Lafitte 2002; Kumar et al. 2008). Field trials are often conducted during the dry season, in which both drought stress and water supply can be managed artificially through irrigation. Managed field drought-screening protocols for reproductive-stage stress tolerance generally fall into the following three categories, depending on the objectives of the drought screen; stress being imposed (i) as a cyclic drought stress (Bernier et al. 2007; Venuprasad et al. 2007, 2008); (ii) at panicle initiation till panicle emergence/heading, followed by rewatering at flowering to study the impact of drought on pollen meiosis and spikelet sterility (Saini and Aspinall 1982); or (iii) to expose the most sensitive flowering stage to drought stress. To account for differences in phenology while using the second and third protocols, either staggered planting or drip irrigation at plot level is followed (Lafitte et al. 2002, 2004). The remaining part of this paper concentrates mainly on studies using the first or third screening protocol, provided severe drought stress coincided with flowering.

Although interactions between drought and high temperature have been observed (Rang et al. 2011), drought tolerance does not necessarily confer heat tolerance; indeed, many drought-tolerant cultivars have been shown to be highly sensitive to heat stress (Jagadish et al. 2007, 2008, 2010a,2010b; see also Craufurd et al. 2003 for peanut). Moreover, the rice gene pool has large genotypic variation for tolerance of heat stress (Jagadish et al. 2008); thus, although all accessions in a drought screen experience similar exposure to high temperature at flowering, tolerance of heat stress varies among the accessions. Unless experiments are designed to account for combined tolerance of drought and heat stress, the interpretation of results from dryseason drought screens in the field will be confounded by the influence of heat stress.

Case studies involving drought screening at International Rice Research Institute (IRRI) and India are considered for addressing the hypothesis of heat stress influencing dry season drought screening. A large proportion of drought screening at the IRRI in Los Baños, Philippines $\left(14^{\circ} 10^{\prime} \mathrm{N}, 121^{\circ} 15^{\prime} \mathrm{E}\right)$, is conducted during the dry season, which runs from January to mid-May. The flowering period in these experiments is generally from March to April (Lafitte et al. 2004; Venuprasad et al. 2007, 2008; Kumar et al. 2008), when rainfall is minimal, allowing 
efficient application of drought stress. IRRI experimental farm weather records from 1979 to 2008 show average maximum temperatures of 32 and $34^{\circ} \mathrm{C}$ and high $\mathrm{RH}$ of 80 and $78 \%$ in March and April, respectively. Since the weather data provides a measure of ambient air temperature $2 \mathrm{~m}$ above the crop canopy, with progressive drought, canopy and tissue temperatures can rise much higher than the ambient temperature, as discussed previously (Fig. 2; Garrity and O'Toole 1995).

There are several rice cultivars that have been studied extensively, for which the extent of drought and heat tolerance are known. These include N22 (heat and drought tolerant: Selote and Chopra 2004; Prasad et al. 2006; Jagadish et al. 2008), Moroberekan and Azucena (drought tolerant but susceptible to heat stress; Champoux et al. 1995; Babu et al. 2001; Sharma et al. 2002; Hittalmani et al. 2004; Jagadish et al. 2007, 2008, 2010a), and IR64 (moderate heat tolerant, sensitive to drought stress; Liu et al. 2006; Jagadish et al. 2008). The percentage reduction in grain yield of Moroberekan and Azucena, N22 and IR64 in field experiments conducted in the dry season (2005) and wet season (2008) at IRRI and the average maximum monthly temperature are shown in (Fig. 3a). Although the intensity and duration of stress varied between seasons, the drought-sensitive and moderately heat tolerant check IR64 (Jagadish et al. 2008) provides an indication of the level of stress. Drought-tolerant checks Moroberekan and Azucena had a greater reduction in grain yield under drought stress in the dry season relative to IR64, but this trend was reversed in the wet season. Other studies with Moroberekan show similar effects in wet and dry seasons (Babu et al. 2001; Hittalmani et al. 2004; Liu et al. 2006; Table 2). We hypothesise that this is due to higher temperatures rather than drought stress, as Moroberekan and Azucena are extremely sensitive to heat stress (Jagadish et al. 2008, 2010a). Across both seasons, N22 had a significantly lower yield decline than the other entries, indicating better heat and drought tolerance (Yoshida et al. 1981; Prasad et al. 2006; Jagadish et al. 2008). Recently, we have also shown under controlled drought at anthesis ( $\sim 50 \%$ flag leaf RWC) that the spikelet fertility of Moroberekan was not significantly different from N22. However, under combined heat and drought stress at anthesis spikelet fertility was significantly reduced $(P<0.01)$ in Moroberekan compared with N22 (Fig. 3b; Rang et al. 2011). The ability to tolerate drought with an efficient antioxidant defence mechanism in N22 panicles has been reported by Selote and Chopra (2004).

Although many other factors such as difference in the severity of the stress, management, and genotype $\times$ environment interactions may have also contributed to the differences in yield, the better performance of other drought-tolerant checks indicates that they may be good heat avoiders (i.e. low canopy temperature; Garrity and O'Toole 1995), possess development traits contributing to heat escape (i.e. early morning flowering; Sheehy et al. 2005) or have true heat tolerance (Yoshida et al. 1981; Jagadish et al. 2008; Weerakoon et al. 2008). In peanut, some of the most drought tolerant lines also possess good heat tolerance (Craufurd et al. 2003).

The co-location or otherwise of quantitative trait loci (QTL) for heat and drought tolerance also provide some insight into these heat and drought interactions. Azucena, which is drought tolerant but susceptible to heat stress (Jagadish et al. 2008), has been used in developing several mapping populations used for studying
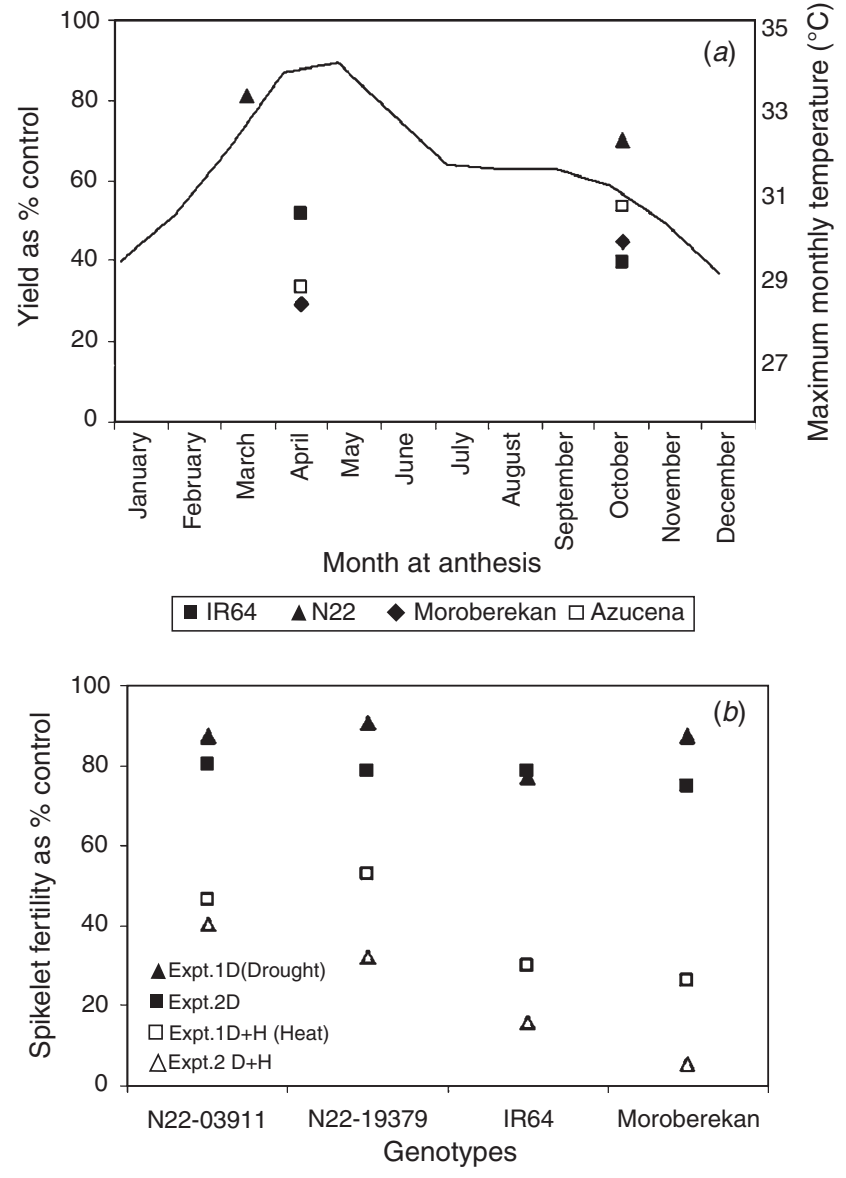

Fig. 3. (a) Mean percentage reduction in rice grain yield under water stress relative to well watered plots is presented for varieties IR64 (drought-sensitive check), N22, Moroberekan (drought-tolerant check) and Azucena. Each data point is an average of four replications of 1 linear meter (J. E. Cairns and R. Lafitte, unpubl. data). Dry-season experiments were sown in January 2005, with flowering in March and April. Drought stress was imposed at flowering using a drip irrigation system. Wet-season experiments were sown between June and August 2007. After establishment in the drought treatments, plants relied on rainfall. Only plots in which flowering coincided with a period of natural drought stress were included. Temperature data was obtained from the IRRI Climate Unit and collected from the IRRI lowland agro-meteorological weather station during 1979-2008. (b) Two independent experiments with flowering in rice exposed to drought (closed symbols) and combined high temperature and drought stress (open symbols) with the duration of high temperature differing from $2-4$ days between the first and second experiments, respectively. N22 was the most tolerant to both stresses even with longer duration of high temperature stress while Moroberekan performed equally well under mild drought stress but recorded close to complete sterility with four days of high temperature stress at flowering (Rang et al. 2011).

drought tolerance in particular. For example, in the Bala/Azucena mapping population, QTL for root traits conferring drought tolerance and grain yield were co-located in wet season experiments in southern India (Gomez et al. 2006), but poorly co-located under drought stress in the dry season at IRRI (Lafitte et al. 2004). More recently, Jagadish et al. (2010b) identified QTL for heat tolerance during anthesis in the same mapping population. They found the most significant and consistent QTL for spikelet fertility under heat stress, 
Table 2. Performance of (rice) Moroberekan and drought tolerant checks during dry season drought screening at IRRI, Philippines and wet season screening at Raipur, India respectively during 2008

Grain yield reduction was calculated as a percent of stress/non-stress

\begin{tabular}{lccccr}
\hline Season & Temperature & Entry & \multicolumn{2}{c}{ Grain yield $\left(\mathrm{t} \mathrm{ha}^{-1}\right)$} & \multicolumn{2}{c}{ Percent } \\
& $\left({ }^{\circ} \mathrm{C}\right)$ & & Non-stress & Stress & reduction \\
\hline Dry season & $24-34$ & Moroberekan & 2.36 & 0.44 & 81.5 \\
& & check - IR77298-14-1-2-10 & 4.90 & 1.75 & 64.0 \\
& & SE & 0.52 & 0.33 & - \\
Wet season & $24-30$ & Moroberekan & 3.33 & 1.55 & 53.0 \\
& & check - IR42253 & 5.50 & 2.61 & 53.0 \\
& & SE & 0.77 & 0.46 & - \\
\hline
\end{tabular}

accounting for nearly $18 \%$ of the phenotypic variation, on chromosome 1. There was, however, no co-location between QTL for spikelet fertility under ambient and heat stress conditions. The QTL for heat stress was in the same physical location on the rice genome as drought and other stress QTL (e.g. Kumar et al. 2007; Jagadish et al. 2010b). Similarly, Pinto et al. (2010) using Seri $\times$ Babax wheat (Triticum aestivum L.) mapping population identified QTL for cooler canopy temperature co-localising for both drought and heat stress under field conditions.

Transcript profiling in tobacco and Arabidopsis (Arabidopsis thaliana (L.) Heynh cv. Columbia) showed lower expression of dehydrins (stress proteins involved in protection against dehydration; Allagulova et al. 2003) under combined heat and drought stress than with drought stress only, whereas heat shock proteins had greater expression under combined heat and drought stress than with either heat or drought stress alone (Rizhsky et al. 2002, 2004). A similar response has been observed in the desert legume Retama raetam (White Broom; Pnueli et al. 2002), indicating comparative responses across species. Recently, a comprehensive compilation of transcripts and metabolic changes to combined drought and heat stress showed $>770$ transcripts and unique metabolites, especially sugars, altered under combined stress that were not altered by either drought or heat stress (Mittler 2006). Using 'the stress matrix', Mittler (2006) emphasised the study of abiotic stress combinations as a new state of abiotic stress rather than just a sum of two different stresses.

These QTL and molecular analyses suggests that certain chromosomal regions, genes and metabolic pathways are responsive to both companions of stresses, with a certain proportion being particularly responsive to either of these two stresses. Most importantly, these studies highlight the interaction of heat and drought stress during the dry-season screening and raise important questions for future drought research. The hidden effects of high temperatures during flowering-stage drought screening can lead to confounding results and screening outputs (germplasm, QTL and candidate genes), which may not translate into gains in drought tolerance in the target environment.

\section{Conclusions}

Managed drought screens in the dry season are often exposed to high-temperature stress, confounding drought screening. Hence, caution should be exercised in interpreting cultivars or candidate
QTL or genes from these trials, as drought-tolerant entries highly susceptible to heat stress during anthesis or flowering could be discarded. Potential drought tolerant material should be further tested under cooler wet season to identify true drought tolerant varieties. Conversely, dry season screening may also involve selecting for heat tolerance, which will be needed as global temperatures are predicted to increase. Further physiological and molecular analysis using well planned controlled environment and field studies are needed to understand the impact of the combined heat and drought stress on rice growth and productivity. Furthermore, to ensure developing crops that can cope with the rapidly changing climate, stress-tolerant germplasm has to be evaluated for stress defence and yield potential under multiple abiotic stresses occurring in farmers fields before release for commercial cultivation.

\section{Acknowledgements}

The first author was financially supported by Felix Scholarship, University of Reading for his doctoral studies. The authors are also grateful for the support of grants from the Bill and Melinda Gates Foundation, USAID (CSISA), and Rockefeller Foundation grant to Indira Gandhi Krishi Viswavidyalaya, Raipur, India. We thank Dr Renee Lafitte, Flor Adrian Simborio, and Grace Centeno for valuable assistance. Drs Abdelbagi Ismail, Horgan Finbarr from IRRI and Dr Vincent Vadez from ICRISAT are thanked for their comments on the manuscript. Bill Hardy is thanked for editing the manuscript.

\section{References}

Alberto MCR, Wassmann R, Hirano T, Miyata T, Kumar A, Padre A, Amante $\mathrm{M}$ (2009) $\mathrm{CO}_{2}$ /heat fluxes in rice fields: comparative assessment of flooded and non-flooded fields in the Philippines. Agricultural and Forest Meteorology 149, 1737-1750. doi:10.1016/j.agrformet.2009. 06.003

Allagulova ChR, Gimalov FR, Shakirova FM, Vakhitov VA (2003) The plant dehydrins: structure and putative functions. Biochemistry 68, 945-951.

Allah AAA, Ammar MH, Badawi AT (2010) Screening rice genotypes for drought resistance in Egypt. Journal of Plant Breeding and Crop Science 2, 205-215.

Atlin GN, Lafitte HR (2002) Marker-assisted breeding versus direct selection for drought tolerance in rice. In 'Field screening for drought tolerance in crop plants with emphasis on rice. Proceedings of an international workshop on field screening for drought tolerance in rice'. (Eds NP Saxena, JC O'Toole) pp. 71-82. (ICRISAT, Patancheru, Andhra Pradesh: India)

Atlin GN, Lafitte HR, Tao D, Laza M, Amante M, Courtois B (2006) Developing rice cultivars for high-fertility upland systems in the Asian tropics. Field Crops Research 97, 43-52. doi:10.1016/j.fcr.2005.08.014 
Babu RC, Shashidhar HE, Lilley JM, Thanh ND, Ray JD, Sadasivam S, Sarkarang S, O'Toole JC, Nguyen HT (2001) Variation in root penetration ability, osmotic adjustment and dehydration tolerance among accessions of rice adapted to rainfed lowland and upland ecosystems. Plant Breeding 120, 233-238. doi:10.1046/j.1439-0523.2001.00578.x

Barnabás B, Jäger K, Fehär A (2008) The effect of drought and heat stress on reproductive processes in cereals. Plant, Cell \& Environment 31, 11-38.

Battisti DS, Naylor RL (2009) Historical warnings of future food insecurity with unprecedented seasonal heat. Science 323, 240-244. doi:10.1126/ science. 1164363

Bernier J, Kumar A, Ramaiah V, Spaner D, Atlin GN (2007) A large-effect QTL for grain yield under reproductive-stage drought stress in upland rice. Crop Science 47, 507-516. doi:10.2135/cropsci2006.07.0495

Boonjung H, Fukai S (1996) Effects of soil water deficit at different growth stages on rice growth and yield under upland conditions. 2. Phenology, biomass production and yield. Field Crops Research 48, 47-55. doi:10.1016/0378-4290(96)00039-1

Boonlertnirun S, Sarobol ED, Meechoui S, Sooksathan I (2007) Drought recovery and grain yield potential of rice after chitosan application. Kasetsart Journal: Natural Science 41, 1-6.

Ceccarelli S, Grando S, Baum M, Udupa SM (2004) Breeding for drought resistance in a changing climate. Challenges and strategies for dryland agriculture. CSSA Special Publication No. 32. Madison, WI, USA.

Champoux MC, Wang G, Sarkarung S, Mackill DJ, O'Toole JC, Huang N, McCouch SR (1995) Locating genes associated with root morphology and drought avoidance in rice via linkage to molecular markers. Theoretical and Applied Genetics 90, 969-981. doi:10.1007/BF00222910

Cohen Y, Alchanatis V, Meron M, Saranga Y, Tsipris J (2005) Estimation of leaf water potential by thermal imagery and spatial analysis. Journal of Experimental Botany 56, 1843-1852. doi:10.1093/jxb/eri174

Craufurd PQ, Peacock JM (1993) Effect of heat and drought stress on sorghum. Experimental Agriculture 29, 77-86. doi:10.1017/ S0014479700020421

Craufurd PQ, Prasad PVV, Kakani VG, Wheeler TR, Nigam SN (2003) Heat tolerance in groundnut. Field Crops Research 80, 63-77. doi:10.1016/ S0378-4290(02)00155-7

Cruz RT, O'Toole JC (1984) Dry land rice response to an irrigation gradient at flowering stage. Journal of Agronomy 76, 178-183. doi:10.2134/ agronj1984.00021962007600020003x

Ekanayake IJ, De Datta SK, Steponkus PL (1989) Spikelet sterility and flowering response of rice to water stress at anthesis. Annals of Botany 63, 257-264.

Fischer KS, Edmeades GO, Johnson EC (1989) Selection for the improvement of maize yield under moisture deficits. Field Crops Research 22, 227-243. doi:10.1016/0378-4290(89)90094-4

Fitzgerald MA, Resurreccion AP (2009b) Maintaining the yield of edible rice in a warming world. Functional Plant Biology 36, 1037-1045. doi:10.1071/FP09055

Fitzgerald MA, McCouch SR, Hall RD (2009a) Not just a grain of rice: the quest for quality. Trends in Plant Science 14, 133-139. doi:10.1016/ j.tplants.2008.12.004

Garrity DP, O'Toole JC (1994) Screening rice for drought resistance at the reproductive phase. Field Crops Research 39, 99-110. doi:10.1016/ 0378-4290(94)90012-4

Garrity DP, O'Toole JC (1995) Selection for reproductive stage drought avoidance in rice, using infrared thermometry. Agronomy Journal 87, 773-779. doi:10.2134/agronj1995.00021962008700040027x

Gomez MS, Kumar SS, Jeyaprakash P, Suresh R, Biji KR, Boopathi NM, Price AH, Chandra Babu R (2006) Mapping QTLs linked to physiomorphological and plant production traits under drought stress in rice (Oryza sativa L.) in the target environment. American Journal of Biochemistry and Biotechnology 2, 161-169. doi:10.3844/ajbbsp.2006. 161.169
Hittalmani S, Hamareddy BG, Shashidhar HE, Girish TN, Grace S, Selvi A, Vaishali MG, Nagabhushan K, Gowda A, Rudresh NS, Kumar S (2004) Impact of moisture stress at different reproductive stages of plant growth on grain yield parameters and marker assisted QTL pyramiding for root length in rice. In 'Resilient crops for water limited environments. Proceedings of a workshop held at Cuernavaca, CIMMYT, Mexico'. (Eds DA Poland, M Sawkins, JM Ribaut, D Hosington) (CIMMYT: Mexico)

IPCC (2007) Summary for policy makers. In: 'Climate Change 2007: The physical science basis. Contribution of Working Group I to the Fourth Assessment Report of the Intergovernmental Panel on Climate Change.' (Eds SD Solomon, M Qin, Z Manning, M Chen, M Marquis, KB Avery, M Tignor, HL Miller) (Cambridge University Press: UK)

Ishimaru T, Hirabayashi H, Ida M, Takai T, San-Oh YA, Yoshinaga S, Ando I, Ogawa T, Kondo M (2010) A genetic resource for early-morning flowering trait of wild rice Oryza officinalis to mitigate high temperature-induced spikelet sterility at anthesis. Annals of Botany 106, 515-520. doi:10.1093/aob/mcq124

Jagadish SVK, Craufurd PQ, Wheeler TR (2007) High temperature stress and spikelet fertility in rice (Oryza sativa L.). Journal of Experimental Botany 58, 1627-1635. doi:10.1093/jxb/erm003

Jagadish SVK, Craufurd PQ, Wheeler TR (2008) Phenotyping parents of mapping populations of rice (Oryza sativa L.) for heat tolerance during anthesis. Crop Science 48, 1140-1146. doi:10.2135/cropsci2007. 10.0559

Jagadish SVK, Muthurajan R, Oane R, Wheeler TR, Heuer S, Bennett J, Crafurd PQ (2010a) Physiological and proteomic approaches to dissect reproductive stage heat tolerance in rice (Oryza sativa L.). Journal of Experimental Botany 61, 143-156. doi:10.1093/jxb/erp289

Jagadish SVK, Cairns J, Lafitte R, Wheeler TR, Price AH, Craufurd PQ (2010b) Genetic analysis of heat tolerance at anthesis in rice (Oryza sativa L.). Crop Science 50, 1633-1641. doi:10.2135/cropsci2009.09. 0516

Jongdee B, Fukai S, Cooper M (2002) Leaf water potential and osmotic adjustment as physiological traits to improve drought tolerance in rice. Field Crops Research 76, 153-163. doi:10.1016/S0378-4290(02) 00036-9

Jongdee B, Pantuwan G, Fukai S, Fischer K (2006) Improving drought tolerance in rainfed lowland rice: an example from Thailand. Agricultural Water Management 80, 225-240. doi:10.1016/j.agwat. 2005.07.015

Kakani VG, Prasad PVV, Craufurd PQ, Wheeler TR (2002) Response of in vitro pollen germination and pollen tube growth of groundnut (Arachis hypogaea L.) genotypes to temperature. Plant, Cell \& Environment 25, 1651-1661. doi:10.1046/j.1365-3040.2002.00943.x

Kobata T, Uemuki N (2004) High temperatures during the grain-filling period do not reduce the potential grain dry matter increase of rice. Agronomy Journal 96, 406-414. doi:10.2134/agronj2004.0406

Kumar R, Venuprasad R, Atlin GN (2007) Genetic analysis of rainfed lowland rice drought tolerance under naturally-occurring stress in eastern India: heritability and QTL effects. Field Crops Research 103, 42-52. doi:10.1016/j.fcr.2007.04.013

Kumar A, Bernier J, Verulkar S, Lafitte HR, Atlin GN (2008) Breeding for drought tolerance: direct selection for yield, response to selection and use of drought-tolerant donors in upland and lowland-adapted populations. Field Crops Research 107, 221-231. doi:10.1016/j.fcr. 2008.02.007

Lafitte HR, Courtois B, Arradeau M (2002) Genetic improvement of rice in aerobic systems: progress from yield to genes. Field Crops Research 75, 171-190. doi:10.1016/S0378-4290(02)00025-4

Lafitte HR, Price AH, Courtois B (2004) Yield responses to water deficit in an upland rice mapping population: associations among traits and genetic markers. Theoretical and Applied Genetics 109, 1237-1246. doi:10.1007/ s00122-004-1731-8 
Lilley JM, Fukai S (1994) Effect of timing and severity of water deficit on four diverse rice cultivars. 1. Rooting pattern and soil water extraction. Field Crops Research 37, 205-213. doi:10.1016/0378-4290(94) 90099-X

Liu JX, Bennett J (2010) Reversible and irreversible drought-induced changes in the anther proteome of rice (Oryza sativa L.) genotypes IR64 and Moroberekan. Molecular Plant doi:10.1093/mp/ssq039

Liu JX, Liao DQ, Oane R, Estenor L, Yang XE, Li ZC, Bennett J (2006) Genetic variation in the sensitivity of anther dehiscence to drought stress in rice. Field Crops Research 97, 87-100. doi:10.1016/j.fcr.2005. 08.019

Long SP, Ort DR (2010) More than taking the heat: crops and global change. Current Opinion in Plant Biology 13, 240-247. doi:10.1016/j.pbi.2010. 04.008

Mackill DJ, Coffman WR, Garrity DP (1996) Varietal improvement for rainfed lowland rice in south and southeast Asia: results of a survey. In 'Rainfed lowland rice improvement'. p. 242. (International Rice Research Institute: Manila, Philippines)

Maclean JL, Dawe DC, Hardy B, Hettel GP (2003) 'Rice almanac.' 3rd edn. (International Rice Research Institute: Los Banos, Philippines)

Matsui T, Omasa K (2002) Rice (Oryza sativa L) cultivars tolerant to high temperature at flowering: anther characteristics. Annals of Botany 89, 683-687. doi:10.1093/aob/mcf112

Matsui T, Namuco OS, Ziska LH, Horie T (1997a) Effect of high temperature and $\mathrm{CO}_{2}$ concentration on spikelet sterility in indica rice. Field Crops Research 51, 213-219. doi:10.1016/S0378-4290(96)03451-X

Matsui T, Omasa K, Horie T (1997b) High temperature induced florets sterility of japonica rice at flowering in relation to air temperature, humidity and wind velocity condition. Nihon Sakumotsu Gakkai Kiji 66, 449-455.

Matsui T, Omasa K, Horie T (2000) High temperature at flowering inhibits swelling of pollen grains, a driving force for thecae dehiscence in rice (Oryza sativa L.). Plant Production Science 3, 430-434. doi:10.1626/ pps.3.430

Mittler R (2006) Abiotic stress, the field environment and stress combination. Trends in Plant Science 11, 15-19. doi:10.1016/j.tplants.2005.11.002

Moffat AS (2002) Plant genetics: finding new ways to protect droughtstricken plants. Science 296, 1226-1229. doi:10.1126/science.296.5571. 1226

Nguyen GN, Hailstones DL, Wilkes M, Sutton BG (2009) Drought-induced oxidative conditions in rice anthers leading to a programmed cell death and pollen abortion. Journal Agronomy \& Crop Science 195, 157-164. doi:10.1111/j.1439-037X.2008.00357.x

O’Toole JC, Namuco OS (1983) Role of panicle exertion in water-stress induced sterility. Crop Science 23, 1093-1097. doi:10.2135/cropsci1983. 0011183X002300060017x

Ouk M, Basnayake J, Tsubo M, Fukai S, Fischer KS, Cooper M, Nesbitt M (2006) Use of drought response index for identification of drought tolerant genotypes in rainfed lowland rice. Field Crops Research 99, 48-58. doi:10.1016/j.fcr.2006.03.003

Pandey S, Bhandari H, Hardy B (2007) 'Economic costs of drought and rice farmers. Coping mechanisms: a cross-country comparative analysis.' (International Rice Research Institute: Manila, Philippines)

Pantuwan G, Fukai S, Cooper M, Rajatasereekul S, O’ Toole JC (2002a) Yield response of rice (Oryza sativa L.) to drought under rainfed lowlands. 3. Plant factors contributing to drought resistance. Field Crops Research 73, 181-200. doi:10.1016/S0378-4290(01)00194-0

Pantuwan G, Fukai S, Cooper M, Rajatasereekul S, O’Toole JC (2002b) Yield response of rice (Oryza sativa L.) genotypes to different types of drought under rainfed lowlands. II. Selection of drought resistance genotypes. Field Crops Research 73, 169-180. doi:10.1016/S03784290(01)00195-2

Pinheiro B da S, De Castro E da M, Guimaräes CM (2006) Sustainability and profitability of aerobic rice production in Brazil. Field Crops Research 97, 34-42. doi:10.1016/j.fcr.2005.08.013
Pinto RS, Reynolds MP, Mathews KL, McIntyre CL, Olivares-Villegas JJ, Chapman SC (2010) Heat and drought adaptive QTL in a wheat population designed to minimize confounding agronomic effects. Theoretical and Applied Genetics 121, 1001-1021. doi:10.1007/ s00122-010-1351-4

Pnueli L, Hallak-Herr E, Rozenberg M, Cohen M, Goloubinoff P, Kaplan A, Mittler R (2002) Mechanisms of dormancy and drought tolerance in the desert legume Retama raetam. The Plant Journal 31, 319-330. doi:10.1046/j.1365-313X.2002.01364.x

Prasad PVV, Boote KJ, Allen LH, Sheehy JE, Thomas JMG (2006) Species, ecotype and cultivar differences in spikelet fertility and harvest index of rice in response to high temperature stress. Field Crops Research 95, 398-411. doi:10.1016/j.fcr.2005.04.008

Rang ZW, Jagadish SVK, Zhou QM, Craufurd PQ, Heuer S (2011) Effect of heat and drought stress on pollen germination and spikelet fertility in rice. Environmental and Experimental Botany 70, 58-65. doi:10.1016/ j.envexpbot.2010.08.009

Rizhsky L, Hongjian L, Mittler R (2002) The combined effect of drought stress and heat shock on gene expression in tobacco. Plant Physiology 130, 1143-1151. doi:10.1104/pp.006858

Rizhsky L, Liang H, Shuman J, Shulaev V, Davletova S, Mittler R (2004) When defense pathways collide: the response of Arabidopsis to a combination of drought and heat stress. Plant Physiology 134, 1683-1696. doi:10.1104/pp.103.033431

Saini HS, Aspinall D (1982) Abnormal sporogenesis in wheat (Triticum aestivum L.) induced by short period of high temperature. Annals of Botany 49, 835-846.

Savin R, Nicolas ME (1996) Effects of short periods of drought and high temperature on grain growth and starch accumulation of two malting barley cultivars. Journal of Plant Physiology 23, 201-210.

Selote DS, Chopra RK (2004) Drought induced spikelet sterility is associated with an inefficient antioxidant defense in rice panicles. Physiologia Plantarum 121, 462-471. doi:10.1111/j.1399-3054.2004.00341.x

Shah N, Paulsen G (2003) Interaction of drought and high temperature on photosynthesis and grain-filling of wheat. Plant and Soil 257, 219-226. doi:10.1023/A:1026237816578

Sharma N, Shashidhar HS, Hittalmani S (2002) Root length specific SCAR marker in rice (Oryza sativa L.). Rice Genetics Newsletter 19, 47-49.

Sheehy JE, Elmido A, Centeno G, Pablico P (2005) Searching for new plants for climate change. Journal of Agriculture Meteorology 60, 463-468.

Sheoran IS, Saini HS (1996) Drought induced male sterility in rice: changes in carbohydrate levels and enzyme activities associated with inhibition of starch accumulation in pollen. Sexual Plant Reproduction 9, 161-169. doi:10.1007/BF02221396

Siddiq EA (2006) Field crops: rice. In 'Handbook of agriculture'. pp. 817-844. (Indian Council of Agricultural Research: New Delhi)

Singh VP, Singh RK, Singh BB, Seigler RS (1996) Physiology of stress tolerance in rice. In 'Proceedings of the International Conference on Stress Physiology of Rice, Lucknow, UP India'. (International Rice Research Institute: Los Banos, Philippines)

Steele KA, Virk DS, Kumar R, Prasad SC, Witcombe JR (2007) Field evaluation of upland rice lines selected for QTLs controlling root traits. Field Crops Research 101, 180-186. doi:10.1016/j.fcr.2006.11.002

Takeoka Y, Hiroi K, Kitano H, Wada T (1991) Pistil hyperplasia in rice spikelets as affected by heat-stress. Sexual Plant Reproduction 4, 39-43. doi:10.1007/BF00194570

Takeoka Y, Al Mamun A, Wada T, Kaufman PB (1992) Primary features of the effect of environmental stress on rice spikelet morphogenesis. Reproductive adaptation of rice to environmental Stress. Developments in Crop Science 22, 113-141.

Vani B, Pardha Saradhi P, Mohanty P (2001) Alteration in chloroplast structure and thylakoid membrane composition due to in vivo heat treatment of rice seedlings: correlation with the functional changes. Journal of Plant Physiology 158, 583-592. doi:10.1078/0176-161700260 
Vara Prasad PV, Craufurd PQ, Summerfield KJ, Wheeler TR (2000) Effects of short episodes of heat stress on flower production and fruit-set of groundnut (Arachis hypogea L.). Journal of Experimental Botany 51, 777-784. doi:10.1093/jexbot/51.345.777

Vara Prasad PV, Craufurd PQ, Kakani VG, Wheeler TR, Boote KJ (2001) Influence of high temperature during pre- and post-anthesis stages of floral development on fruit-set and pollen germination in peanut. Australian Journal of Plant Physiology 28, 233-240.

Vara Prasad PV, Boote KJ, Hartwell LA Jr (2006) Adverse high temperature effects on pollen viability, seed-set, seed yield and harvest index of grainsorghum (Sorghum bicolor (L.) Moench) are more severe at elevated carbon dioxide due to higher tissue temperatures. Agricultural and Forest Meteorology 139, 237-251. doi:10.1016/j.agrformet.2006.07.003

Venuprasad R, Lafitte HR, Atlin GN (2007) Response to direct selection for grain yield under drought stress in rice. Crop Science 47, 285-293. doi:10.2135/cropsci2006.03.0181

Venuprasad R, Sta Cruz MT, Amante M, Magbanua R, Kumar A, Atlin GN (2008) Response to two cycles of divergent selection for grain yield under drought stress in four rice breeding populations. Field Crops Research 107, 232-244. doi:10.1016/j.fcr.2008.02.004

Verulkar SB, Mandal NP, Dwivedi JL, Singh BN, Sinha PK, Mahato RN, Dongre P, Singh ON, Bose LK, Swain P, Robin S, Chandrababu R, Senthil S, Jain A, Shashidhar HE, Hittalmani S, Vera Cruz C, Paris T, Raman A, Haefele S, Serraj R, Atlin G, Kumar A (2010) Breeding resilient and productive genotypes adapted to drought-prone rainfed ecosystem of India. Field Crops Research 117, 197-208. doi:10.1016/j.fcr.2010.03. 005
Virk DS, Singh DN, Prasad SC, Gangwar JS, Witcombe JR (2003) Collaborative and consultative participatory plant breeding of rice for the rainfed uplands of eastern India. Euphytica 132, 95-108. doi:10.1023/ A: 1024674422343

Wassmann R, Jagadish SVK, Sumfleth K, Pathak H, Howell G, Ismail A, Serraj R, Redona E, Singh RK, Heuer S (2009) Regional vulnerability of climate change impacts on Asian rice production and scope for adaptation. Advances in Agronomy 102, 91-133. doi:10.1016/S00652113(09)01003-7

Weerakoon WMV, Maruyama A, Ohba K (2008) Impact of humidity on temperature-induced grain sterility in rice (Oryza sativa L.). Journal Agronomy \& Crop Science 194, 135-140. doi:10.1111/j.1439037X.2008.00293.X

Yoshida S, Satake T, Mackill DS (1981) High temperature stress in rice. IRRI Research Paper Series, 67.

Zhang W, Han Y, Du H (2007) Relationship between canopy temperature at flowering stage and soil water content, yield components in rice. Rice Science 14, 67-70. doi:10.1016/S1672-6308(07)60010-9

Manuscript received 20 November 2010, accepted 9 February 2011 